Article

\title{
Challenges of Urban Living Labs towards the Future of Local Innovation
}

\author{
Aksel Ersoy* and Ellen van Bueren \\ Department of Management in the Built Environment, TU Delft, 2628BL Delft, The Netherlands; \\ E-Mails: a.ersoy@tudelft.nl (A.E.), e.m.vanbueren@tudelft.nl (E.v.B) \\ * Corresponding author
}

Submitted: 3 May 2020 | Accepted: 12 August 2020 | Published: 14 October 2020

\begin{abstract}
Finding new approaches to overcome complex urban problems such as climate change has always been of interest to policymakers and academics. The changing dynamics of urban development result in the diversification of new practices during which experimentation is used to inform urban practice. Amongst these approaches, urban living labs (ULLs) have become a popular form of urban experimental innovation in many countries in the last decade. These ULLs respond to the increased complexity of future challenges calling for local solutions that acknowledge the local conditions-political, technical, and social. Even though a great deal of attention has been given to this form of urban innovation, there has been little consideration of the learning and innovation processes within ULLs. Based on a comparative case study of three innovation projects in a ULL in the city of Amsterdam, we analyse and discuss the claims of ULLs regarding innovation and the different orders of learning they foster. We argue that in the processes of experimentation within ULLs, combining mechanisms of learning and innovation is key to promoting the development of particular local solutions. However, since the learning processes are especially concerned within a particular ULL learning setting, there is a mismatch between the expectations of policymakers, industry, citizens, and knowledge institutes, as well as how the lessons learned can be useful for other contexts.
\end{abstract}

\section{Keywords}

Amsterdam; future challenges; learning; local innovation; urban living labs

\section{Issue}

This article is part of the issue "The City of Digital Social Innovators" edited by Chiara Certomà (Ghent University, Belgium), Antonella Passani (T6-Ecosystems, Italy) and Mark Dyer (University of Waikato, New Zealand).

(C) 2020 by the authors; licensee Cogitatio (Lisbon, Portugal). This article is licensed under a Creative Commons Attribution 4.0 International License (CC BY).

\section{Introduction}

There is a growing recognition that cities face complex environmental problems and require multiple and interdisciplinary approaches to overcome their unprecedented challenges. Urban Living Labs (ULLs) are defined as:

A forum for innovation, applied to the development of new products, systems, services, and processes, employing working methods to integrate people into the entire development process as users and co-creators, to explore, examine, experiment, test and evaluate new ideas, scenarios, processes, systems, concepts and creative solutions in complex and real contexts. (JPI Urban Europe, 2013, p. 1)
They aim to overcome important and persistent barriers to implementation and adoption (Franz, Tausz, \& Thiel, 2015), such as the lack of user commitment and the mismatch between policies and innovations and the specific, local physical and institutional environment (Araos et al., 2016; van Bueren \& De Jong, 2007). They provide a co-creative environment, in which multiple stakeholders test, develop, and create solutions to the contemporary challenges of cities. Given the complexity of the urban challenges we face today, ULLs provides an essential platform to create a connection between fundamental research and societal impact by connecting the different disciplines and stakeholders.

It has been argued that the creation of such platforms has a potential to provide an alternative space 
that can facilitate a new ecosystem, interaction, and enable more experimentation (Concilio \& Molinari, 2014; Pereira, Karpouzoglou, Doshi, \& Frantzeskaki, 2015). A more open and transparent way of collaborating can open up change and dialogue between academics, practitioners, and stakeholders from different backgrounds. This not only strengthens the debates between the social sciences and other disciplines but also offers better insights for global environmental change as well as global governance and stewardship (Stone-Jovicich, 2015). While an increasing number of social and environmental challenges require the involvement of actors from different organisations, this interaction stimulates the involvement of non-scientific actors in the context of alternative modes of knowledge production. This is especially crucial as traditional forms of knowledge creation, i.e., disciplinary and primarily cognitive, has been limited and does not capture the broader interdisciplinary social and economic context (Gibbons et al., 1994). New forms of expertise and knowledge are needed to contribute to the societal and environmental problems faced by cities today (Ersoy, 2017; Jasanoff, 2004; Nowotny, Scott, Gibbons, \& Scott, 2001).

ULLs can be placed within the changing dynamics of urban challenges during which experimentation is used to inform urban practice. As part of this process, they adopt participation as key towards achieving their goals of addressing urban sustainability challenges (Juujärvi \& Pesso, 2013; Menny, Palgan, \& McCormick, 2018; Voytenko, McCormick, Evans, \& Schliwa, 2016). Participants help design and develop innovations, and test new ways of addressing sustainability challenges (Bulkeley et al., 2016; Nyström, Leminen, Westerlund, \& Kortelainen, 2014) through an iterative process of feedback loops that involve the design, construction, and use of instruments (Karvonen \& van Heur, 2014). However, since the actors involved in ULLs, understandably, are especially interested in the local outcomes, the articulation of knowledge and learning within ULLs is often absent or lacking (Franz et al., 2015; Schuurman, Baccarne, Marez, Veeckman, \& Ballon, 2016). The production of such formalized knowledge, needed for the replication or upscaling of innovations, is often not a priority for the actors involved. Their attention is often focused on the substantive results, with the achievements being communicated in terms of measurable, successful products and local improvements. Moreover, ULLs have been adopted without much reflection on whether or not they actually achieved their goals. Understanding the multiple dynamics within these active environments is essential as they are the results of complex actions, the socio-spatial system of resources, actors, context issues, and the governance system (Concilio \& Molinari, 2014).

In our article, we explore how learning processes can be conceptualised as part of the innovation processes of ULLs. Based on a comparative case study of three innovation projects within a ULL in the city of Amsterdam, we analyse and discuss the claims of ULLs regarding the learning and innovation taking place. Our cases show that there is an inherent tension between the development of innovations to be adopted elsewhere, by others, and the development of innovations that work in the particular context in which they have been developed. We argue that the process of experimentation allows different orders of learning in ULLs. In such processes, combining mechanisms of learning and innovation is key to promoting the development of particular local solutions.

\section{Open Innovation and Learning within ULLs}

With an increasing awareness that the traditional model of innovation is becoming obsolete, a new paradigm of 'open innovation' has emerged connecting internal and external sources of information-rich environments (Chesbrough, 2003). Open innovation pays attention to improving organisational construction and strategic maintenance as well as enhancing the competitive advantage of firms. Stemming from open innovation, a series of new concepts has been coined to refer to the increasing importance of knowledge creation. While the 'Triple Helix' of university-government-industry relations focuses on the knowledge infrastructure of innovations provided by such relations, it brings new ideas in relation to organized knowledge production in a knowledge-based economy (Leydesdorff, 2006). With the rise of open and user-centric innovation policy, a new form of cooperation, Quadruple Helix, has been discussed as part of a broader cooperation in innovation. As part of this form of cooperation, an era of linear, top-down, expert-driven development of service provision is giving way to different forms and levels of coproduction, involving consumers, customers and citizens, as well as public authorities in the provision of public services (Arnkil, Järvensivu, Koski, \& Piirainen, 2010; Carayannis \& Campbell, 2009). The term coproduction here has been referred to in both management and social sciences literature in a number of different ways. It emphasises dimensions of meaning, discourse, and textuality (Ersoy, 2017) while addressing a number of disciplinary enquiries from political scientists, sociologists, social theorists, and anthropologists (Jasanoff, 2004) to environmental governance and management (Wyborn, 2015). It offers alternative ways of imagining for academics to work with policymakers (Perry \& Atherton, 2017; Polk, 2015).

Similarly, learning initially was conceptualised to manage change in organizations (e.g., Hargrove, 2002), but was soon applied to processes of policy change as well (Bennett \& Howlett, 1992). Three different kinds of learning process have been conceptualised for people, organisations, and groups in order to modify their actions. Amongst them, single and double-learning loops have been used very widely in the literature. Argyris and Schön (1978) used these terms to correspond to the changes in resource governance regimes based on the theory of action. While single-loop learning has 
been said to adapt the behaviour and actions of organisations to mitigate and improve the situation without much reflection on the process, double-loop learning aims to stimulate a deeper understanding of assumptions and the decision-making process. It implies a reflection on goals and problem framing and how goals can be achieved. Triple-loop learning, on the other hand, refers to a transformation of the structural context and factors that determine the frame of reference. Pahl-Wostl (2009, p. 359) argues that "this kind of societal learning refers to transitions of the whole regime (e.g., change in regulatory frameworks, practices in risk management, dominant value structure)." Transforming requires recognition that paradigms and structural constraints impede an effective reframing of resource governance and management practices. It is also possible to conceptualise these loop-learning processes in lower-order and higherorder learning (Brown \& Vergragt, 2008; Brown, Vergragt, Green, \& Berchicci, 2003). While lower-order learning is adaptive and technical, identifying satisfactory solutions to known problems, higher-order learning, in contrast, "entails changes in the assumptions, norms and interpretive frames which govern the decision-making process and actions....or which underlie a policy discourse" (Brown \& Vergragt, 2008, p. 110). It is not a search for satisfactory solutions to a given problem, but the reformulation of problem and process. Individuals who engage in higher- and lower-order learning do so through a process of collective discovery (Cunningham \& Cunningham, 2008).

ULLs, in that respect, aim to enhance open innovation and learning-about what works-and in the process, develop innovation in interactive, participatory, or co-creation processes (Pallot, Trousse, Senach, \& Scapin, 2010). With this knowledge, innovation can be improved and replicated in other places. ULLS aim to bring together multiple actors to be able to address contemporary urban challenges and foster learning through forms of open and engaged learning (Bulkeley et al., 2016). Those actors can contribute to the different phases of the innovation system that is being created by adding their own knowledge, employing a collective learning mechanism (Concilio \& Molinari, 2014; Friedrich, Karlsson, \& Federley, 2013). With the help of an experimental approach in a 'triple' or 'quadruple' helix mode, they bring science, policy, businesses, and civil society together (Lehmann, Frangioni, \& Dubé, 2015; Matti, Edwards-Schachter, \& Alcántara, 2012; Stahlbröst \& Holst, 2013). Their structure can range from universities and science parks adopting user-driven approaches to regional clusters enabling a joint Quadruple Helix approach, as well as social actors and entrepreneurs aiming at excellence-driven innovations at local and international levels (Joint Research Centre, n.d.). The use of such models as the triple or quadruple helix recognises the value of partnerships and the different stakeholders and their roles in facilitating and supporting innovation (Mulvenna, Bergvall-Kåreborn, Wallace, Galbraith,
\& Martin, 2010). Although there have been different interpretations of ULLs, it is possible to identify some of the fundamental characteristics in the literature. For instance, Higgins and Klein (2011) refer to a real-world setting of these labs which brings in multiple stakeholders to interact. These ULLs respond to the increased complexity of urban climate challenges calling for local solutions that acknowledge the local conditions-political, technical, and social. In many ULLs, local innovations to climate problems are being developed, tried and tested, and improved, leading to urban innovations ready for repetition and upscaling. The involvement and participation of local stakeholders and citizens are generally considered as key to delivering solutions that are accepted. Nevertheless, it has been a challenging task to identify a direct link between the learning process and the innovation that take place in ULLs. Recently, Steen and van Bueren (2016) identified the characteristics of ULLs in an earlier study where they formulated the goals of ULLs such as developing new products to find new solutions to existing or new problems, producing and exchanging knowledge of the developed products and processes to achieve these products, and emphasizing the need for supported, local solutions.

Based on the ongoing debate, a conceptual framework has been developed to analyse our cases with a focus on understanding how learning and innovation have been implemented within ULLs (Figure 1). Our analytical framework is based on different loops of learning (Argyris \& Schön, 1978; Brown \& Vergragt, 2008; Brown et al., 2003) where the state-of-the-art of ULLs' innovation process and learning are examined by the operationalisation of the learning and innovation involved and how they are deployed. ULLs that engage in different loops of learning presume a process of collective discovery. One outcome of such a process can be the convergence of perspectives across stakeholders: Greater shared understanding can, in itself, be a successful learning outcome, forming the platform upon which to build future collaboration. Another outcome can be instrumental, i.e., when actors in ULLs learn on an instrumental level, they learn how to display the behavioural change as intended by the co-produced intervention and they can adapt their actions accordingly. This may even imply that they deviate from the intervention, for example, when a system is dynamic, a change of conditions and circumstances calls for modification of behaviour. Alternatively, learning can trigger actors within ULLs to develop a capacity to learn, allowing them to recognize and anticipate changes, and act upon them.

\section{Methodology}

To substantiate and develop our argument, we draw on our empirical material gathered from fieldwork in Buiksloterham, Amsterdam. Buiksloterham is widely perceived to be successful in the context of entrepreneurialism as it hosts diverse and extensive voluntary and community sectors that have developed a self-reliant and 


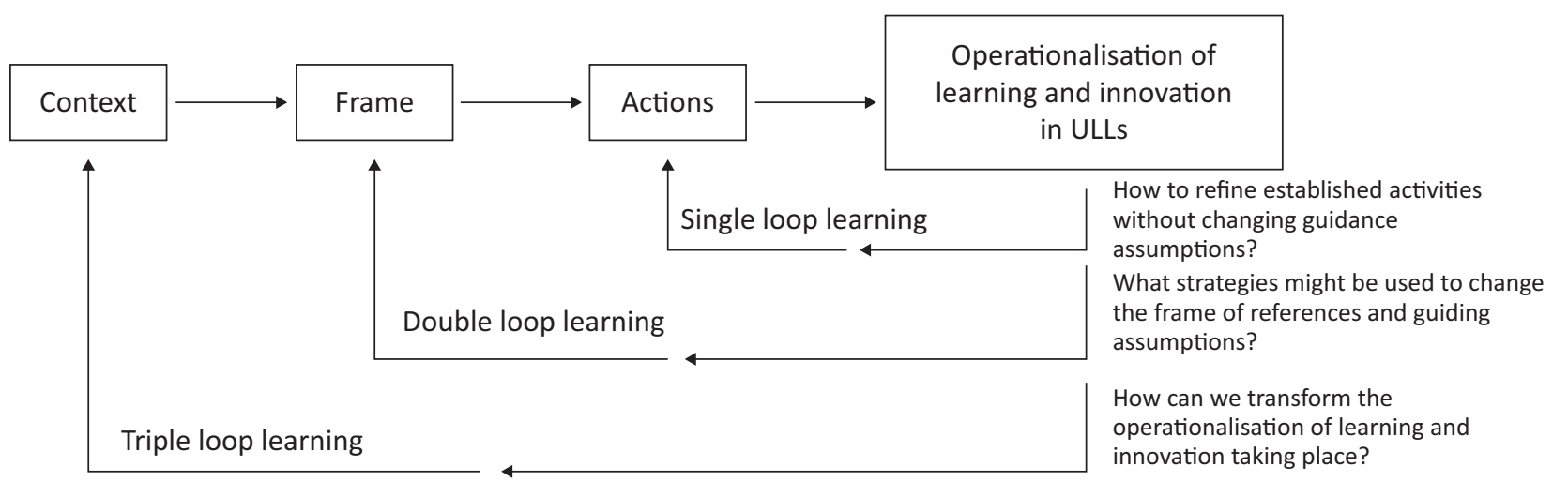

Figure 1. Theoretical framework. Source: Authors, based on Argyris and Schön (1978) and Hargrove (2002).

adversarial relationship with the city and have regularly come together for projects on sustainability and circular development. The article is informed by interviews carried out in 2017 as well as secondary data gathered through fieldwork conducted over 2018 and 2019. Data include newspaper articles, policy documents, academic reports, and official websites. In particular, we use three empirical case studies embedded in the Buiksloterham ULL in Amsterdam to understand the processes of learning in support of local innovation involving citizens. Conducting a case study of three embedded cases allows us to learn more about the rich and dynamic environment within which these developments took place. The selection of these embedded cases has a practical basis: By having the urban transformation of Buiksloterham as a case for education, we were able to actively follow developments in the cases studied over the years and to follow up on the initial analysis and interviews. A thick and context-rich understanding of cases helps to analyse and classify the learning in terms of the single, double, and triple loop-learning that took place, as well as by the different actors involved, and how the governance setting of the living lab contributed to the learning. Finally, we analyse the extent to which the cases have contributed to formalised or codified knowledge that can be shared in the form of replicable innovations. After all, that is what ULL's ultimately want: the city benefitting from knowledge that has been co-produced in an experimental setting.

The interviews that were held for each of the embedded cases, comprised interviews with key stakeholders involved (four for De Ceuvel, three for Schoonschip, four for the Manifesto; two of the interviewees were interviewed for both the case of the De Ceuvel and Schoonschip). Together with the interviewees, a reconstruction of the innovation process was made, supported with a physical timeline reflecting the key moments in the process that influenced its next phases (cf. Teisman, 2000). Interviewees were asked to identify the following in the process: events, decisions of influence (taken by themselves or others), actions, agreements reached, choices made (by themselves or others), as well as drivers or breakthroughs, and any setbacks or barriers in the process. They were also asked to think about influencing contextual factors-e.g., political, legal, economic, social, technological, and environmental factors.

At the beginning, a general timeline of a living lab was prepared with an aim to explore the different stages of an innovation process. With coloured sticky notes and a pen, stakeholders could add events and decisive moments to the process, as well as the contextual factors of influence on the process (see Figure 2 for an impression). The interviewer asked for more explanation while the interviewee was structuring the events. The interviewer was going to put the different timelines together afterwards but would ask during the interviewee for more explanation when recollections of the process and the product developed differed from the other interviewees' information or from the researchers' information from the document analysis carried out prior to the interviews. Consequently, interviewees were confronted with each other's perception of the process, while giving the interviewer, one of the researchers, a more comprehensive image of the process. This also gave the interviewer additional information on the dynamics of the case, e.g., regarding the motivations and interests of actors, the use of resources, the interactions between the actors involved, and the actions taken by different stakeholders. The final timeline and case description were sent to the interviewees for factual correction and feedback on the understanding of the case by the researchers. The interviews were held by the same interviewer, a junior researcher, who discussed the reconstruction and the analysis with the other, senior researcher. With the thorough knowledge of the cases based on the process reconstructions, the cases were also followed in 2018 and 2019 by continued document analysis and annual site visits with students, who analysed the case as part of an assignment in a course on sustainable urban development. The site visits included presentations by, or meet-ups with, stakeholders.

\section{ULLs in Buiksloterham, Amsterdam}

The three cases all took place within the context of the transformation of an industrial waterfront towards 


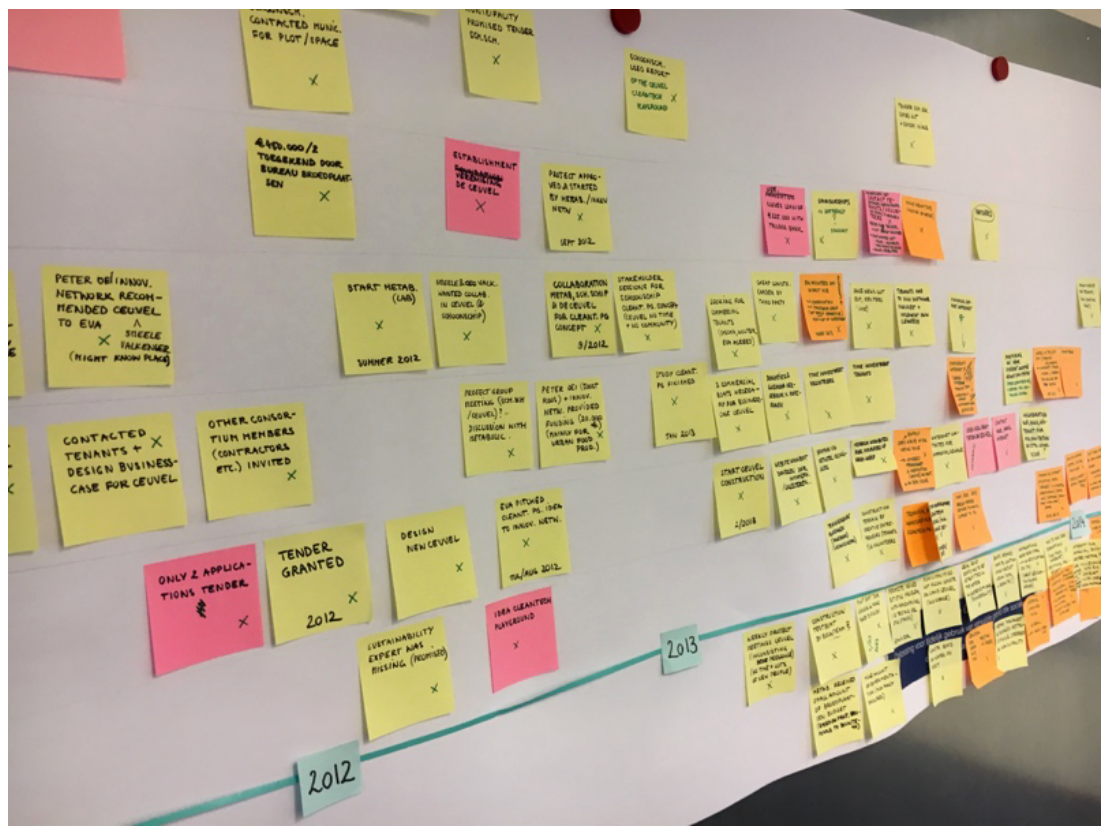

Figure 2. Reconstruction of the timeline by one of the interviewees. Source: Courtesy of Kris Gyselle Steen.

a more mixed use of the area for residential, office, and industrial purposes. In 1999, the plan for the development of the transformation of the area was set in motion. In 2007, on the verge of plans starting to be realised, the financial crisis started: All plans were put on hold by the housing associations and private property developers who had purchased, or acquired development rights to, the land. In the following years, the municipality considered alternative ways to develop the area. It decided to start a process of incremental, or small-scale development of the area, which coincided with initiatives of local entrepreneurs who saw the crisis as an opportunity for replacing the more traditional plans, with a focus on profit and gentrification, with something more environmentally and socially concerned: focusing sustainability and a circular economy. This gave rise to a number of experimental approaches to urban development, with nontraditional stakeholders at the forefront, which as time went by, with the rise of the popularity of the concept amongst policymakers, be understood and generally referred to as ULLs.

In 2012, the municipality organised a contest for the temporary (10-year) use of a parcel of highly polluted land, the former shipyard De Ceuvel, in an attempt to stimulate placemaking activities that would promote the development of Buiksloterham. The plan for the development of an ecological, creative work community by local entrepreneurs, architects, and environmental consultants to put old boats onshore, connected by a boardwalk and with experimental bio-based soil remediation. In the course of time, increasing numbers of 'cleantech,' circular innovations would be tested at De Ceuvel. The community opened in 2014. For the various cleantech innovations, collaboration with specific knowledge institutes and local partners was sought in search of support and knowledge development and dissemination. In 2013, a subsidy of the Ministry of Economic Affairs supported the development of the project and the cleantech innovations in collaboration with another project in the same area, Schoonschip. Metabolic, the environmental consultant and key partner in the De Ceuvel, authored this report and also became involved in Schoonschip. By 2019 , halfway into the 10 -year period, De Ceuvel has become an example of best practice among ULLs, fulfilling the laboratory function, especially in the field of cleantech. In 2020, with the end of the 10-year lease period in sight, the temporary ambition, however, is being contested by the initiators, pointing at the fact that De Ceuvel continues to be a place for real-life innovation and experimentation while also having a communicative function as it hosts numerous visits and is a breeding ground for innovative small or starting enterprises.

Schoonschip is a sustainable floating residential community of 30 houses and about 48 households. Inspired by a pioneer living in a sustainable houseboat, two entrepreneurial individuals started the development of a plan for a sustainable floating community in 2008. Together with future residents, they sought a location. In 2010, they focused on a canal in Buiksloterham and they managed to get the municipality to tender the development of a plot there: Schoonschip, well-prepared and supported by future residents/community members, won the tender. In the further development of the technological innovations in the plan, mainly focusing on the reduction of waste and environmental impact of resource use, collaboration was sought with De Ceuvel, where partners were also looking for minimum impact technologies. They looked also for a project partner and knowledge institutes from The Netherlands and abroad who could support the development and implementa- 
tion of sustainable technologies (e.g., sanitation, smart grid). In December 2018, the first seven floating houses arrived, the other 23 followed in 2019.

In 2007, at the start of the financial crisis, a local entrepreneur founded New Energy Docks, a temporary community of practice in Buiksloterham for companies aiming to bring sustainable solutions to the market. With plans for the area being put on hold due to the crisis, the temporary housing of the community became longer-term and the community started to play an active role in thinking of alternative, sustainable ambitions for the area. In 2010, the municipality handed out the first self-build plots to start small-scale development, to have some development while large players waited. The community of practice and the first self-builders started to collaborate on generating ideas for the sustainable and circular development of the area, along the way being inspired by the plans for De Ceuvel and Schoonschip. In 2011, this evolved into a local Buiksloterham community focusing on the sustainable and circular development of the area. To secure circular ambitions for the area in the future, they lobbied for a manifesto in which stakeholders committed themselves to the circular ambitions for the area as well as a formal status of the area as 'living lab' by the municipality. They were driven by the concern that developments would be resumed once the crisis passed, and stakeholders would fall back on traditional approaches to development and would forget the lessons in sustainable urban innovation that had been learned on in the meantime. Hence, they started to prepare a Manifesto for the circular development of the area, to be signed by all the area's stakeholders.

In April 2015, the Manifesto Circular Buiksloterham was signed by 20 professional private and public stakeholders. With their signatures, they supported the collaborative development of Buiksloterham as an innovative urban laboratory for small-scale innovative concepts. Stakeholders take joint responsibility for the whole area (Gladek, van Odijk, Theuws, \& Herder, 2015). The Manifesto was accompanied by a report on the opportunities for circular development, co-authored by Metabolic, the local environmental consultancy firm that was rapidly growing after having co-initiated De Ceuvel and played a role in the development of the Clean Tech Playground in both De Ceuvel and Schoonschip. Later that year, the city council granted the area Buiksloterham a formal status as 'Living Lab,' with opportunities for a flexible rule regime. This also led to a formalisation of the Buiksloterham-community into a foundation 'City Lab Buiksloterham.' However, the precise meaning of the Living Lab-status was unspecified, as there were no precedents with such status. In the following years, up to 2019, the City Lab played a key role in facilitating the starting up, implementation, and dissemination of sustainable innovations by organizing events such as meet-ups and roundtables, while continuously brokering between the various stakeholders involved. The sustainability ambitions and targets formulated in the three living labs are presented in Table 1. Innovations are considered key to meet these targets.

\section{Results}

In this section, we analyse how the stakeholders in the three ULLs learnt, specified for the different orders of learning. In living labs, combining mechanisms of learning and embedding is key to promoting the development of particular local sustainable solutions. To recall (Section 2), single-loop learning concerns 'improving' without further reflection or adaptation; doubleloop learning concerns the improvement and adaptation based on reflection; and triple-loop learning concerns a transformation, a systemic change. Table 2 shows an overview of a qualitative assessment of the learning resulting from the three living labs, based on the primary and secondary data collected, and the innovations being replicated. Since living labs explicitly focus on the production of formalized knowledge, to be of use to others, in other places, besides the usability for the partners within the living lab, we have focused on the employability of lessons in other projects (learning from the project), and less on the learning within the project.

The three living labs within the Buiksloterham area in Amsterdam all aimed to promote the sustainable development of the area or particular places within that area by developing innovations in both processes and technologies:

The Living Lab status is necessary for establishing the overall character of the neighbourhood as a place where new technologies and management approaches can be applied and learned from. It is also instrumental in releasing developers and residents in the area from some legal restrictions that currently prevent the use of new materials and clean technologies in construction. (Gladek et al., 2015, p. 44)

Especially in the crisis years, from 2007 to roughly 2015/2016, many of the stakeholders were convinced that urban development would never be the same, and future projects would have to be of a small-scale nature, closely involving users and residents, and would be characterized by resource use in closed-loops, at the lowest scale possible to avoid transport losses and contribute to local value. The local experiments and implementation of the innovations developed would lead to lessons that could be applied, or further developed elsewhere.

The case analysis shows the importance of the participation of knowledge institutes and experts (consultants) for learning. They were key actors bringing in testable innovations and funds to do so, even though the ideas were often generated by the local communities involved, while they were also the ones bringing the innovations to other projects. Even though the living labs needed quite some learning on issues as governance, management, and organization, not just by the actors involved, but 
Table 1. Sustainability ambitions and targets stated in three living labs in Amsterdam.

\begin{tabular}{ll}
\hline ULL & Ambitions \\
\hline De Ceuvel: Temporary & 'Featherlight' footprint: minimized \\
workplace for creative & infrastructure on-site, with the possibility to \\
and social enterprises & leave the site without leaving much of a trace. \\
on polluted land & Regenerative development: The \\
& phytoremediation plan and biodiversity \\
& measures will result in a cleaner and more \\
& biodiverse area than at the start of the \\
& project; Fast return on investment: Using a \\
& DIY approach and recycled materials, return \\
& on investment is possible in less than five \\
& years for all recommended interventions.
\end{tabular}

Schoonschip:

Sustainable floating residential community (30 houses, $\approx 48$ households)

Manifesto/Living Lab Circular Buiksloterham to commit key stakeholders in Buiksloterham to sustainable, circular ambitions and goals
Closed material cycles: reuse of nutrients and energy on-site.

Evolving technology landscape: continuous improvement of system performance by adopting new technologies as they become available and affordable.

Shared use of communal facilities will increase community interaction and facilitate resource sharing.

Demand-side management approaches which will limit overall resource demand.

Reuse of nutrients and energy on-site, cascading of heat from waste sources for reuse in other functions (from greenhouses to the community pool).

Evolving technology landscape: continuous improvement of system performance by adopting new technologies as they become available and affordable.

In April 2015, the Manifesto Circular Buiksloterham was signed by 20 professional private and public stakeholders in the area. The Manifesto was supported by a report specifying the circular ambitions for Buiksloterham.

Later in that year, 2015, the municipality granted Buiksloterham a formal status as 'Living Lab,' with opportunities for a flexible rule regime. However, the meaning of this status was unspecified.
Targets

$100 \%$ renewable heat and hot water supply

$100 \%$ renewable electricity

$100 \%$ wastewater and organic waste treatment

$100 \%$ water self-sufficiency

$60 \%-80 \%$ nutrient recovery

$50 \%-70 \%$ reduction in electricity demand over conventional offices

$10 \%-30 \%$ vegetable $\&$ fruit production using locally recovered nutrients

sensor network and real-time system performance displays

$100 \%$ renewable heat and hot water supply $100 \%$ renewable electricity

$100 \%$ wastewater and organic waste treatment

$100 \%$ water self-sufficiency

$60 \%-80 \%$ nutrient recovery

$50 \%-70 \%$ reduction in electricity demand over conventional households

$60 \%-80 \%$ vegetable $\&$ fruit production using locally recovered nutrients sensor network and real-time system performance displays

Technological goals:

Developing BSH as an attractive area for innovations in water management.

Developing and implementing a renewable energy vision.

Developing a plan for sustainable mobility.

Transforming polluted soil to fertile grounds for public value creation.

Closing material flows with keeping value as high as possible and at the appropriate scale.

Systemic goals:

Recognizing BSH as a living lab.

Developing a governance approach supported by all stakeholders.

Developing new financing instruments/structures.

Developing open data monitoring systems. 
also by the environment in which they operated, these lessons do not seem to have been picked up by actors in the wider environment.

With the property market picking up in 2016 and getting rapidly overheated again, many actors regret that the present conditions give no room for adopting the lessons learned during the crisis. With regards to the importance of the involvement of citizens and end-users in the development of innovation, the three living labs show a rather weak engagement of these groups. This may be explained by the technical focus of the labs, and the absence (back then) of many residents in the industrial area when the labs started. This would be a factor to take into account when applying the innovations in other places.

\section{Towards Innovation To Be Replicated}

In a Living Lab, it is essential to harmonise the innovation process amongst stakeholders so that they can benefit from the process in different ways. This can be seen, for example, in how companies can get new and inno-

Table 2. Learning and innovation resulting from three living labs in Amsterdam.

\begin{tabular}{|c|c|c|c|}
\hline ULL & Single-loop learning & Double-loop learning & Triple loop learning \\
\hline $\begin{array}{l}\text { De Ceuvel: } \\
\text { Workplace for } \\
\text { creative and social } \\
\text { enterprises }\end{array}$ & $\begin{array}{l}\text { On particular innovations } \\
\text { (cleantech) by directly } \\
\text { involved actors. The } \\
\text { involvement of a starting } \\
\text { environmental consultant and } \\
\text { landscape architect as } \\
\text { initiators willing to invest a lot } \\
\text { of time to develop the concept } \\
\text { while developing a breeding } \\
\text { location where they could } \\
\text { reside and prove and } \\
\text { showcase their concepts was } \\
\text { key. The land made available } \\
\text { by the municipality for a } \\
\text { 10-year period was essential } \\
\text { for the financial viability of the } \\
\text { plans. The technical } \\
\text { innovations in the plan were } \\
\text { developed with the support of } \\
\text { established knowledge } \\
\text { institutes who knew how to } \\
\text { apply for a subsidy to develop } \\
\text { the innovations. }\end{array}$ & $\begin{array}{l}\text { On the initiation and } \\
\text { development of innovations, } \\
\text { on issues as fundraising, } \\
\text { collaboration, testing, etc. } \\
\text { (e.g., the project } \\
\text { CleanTechPlayground included } \\
\text { learning on cleantech in both } \\
\text { De Ceuvel and Schoonschip). } \\
\text { The initiators involved learned } \\
\text { how to create the conditions } \\
\text { for single-loop learning by } \\
\text { collaborating with established } \\
\text { stakeholders, } \\
\text { well-experienced with raising } \\
\text { (political) support and funding. } \\
\text { In } 2020 \text {, de Ceuvel was still a } \\
\text { place for single-loop and } \\
\text { double-loop learning on } \\
\text { innovations and the conditions } \\
\text { for implementation. }\end{array}$ & $\begin{array}{l}\text { De Ceuvel demonstrates that } \\
\text { it is possible to use polluted } \\
\text { land temporarily for creative } \\
\text { industry breeding places, thus } \\
\text { contributing to 'place-making' } \\
\text { and innovation. By showcasing } \\
\text { the success of the project by } \\
\text { the initiators, promoting the } \\
\text { replicability of the innovations } \\
\text { and the innovation ecosystem } \\
\text { created at De Ceuvel, the } \\
\text { unique project conditions } \\
\text { should be emphasized as well: } \\
\text { free land for a } 10 \text {-year period. } \\
\text { Over the years, De Ceuvel has } \\
\text { become a permanent testing } \\
\text { ground for these initiators, } \\
\text { which they would like to keep. } \\
\text { This is at odds with the } \\
\text { temporary concept of the plan } \\
\text { and could potentially reduce } \\
\text { De Ceuvel's innovative } \\
\text { character, urging it to operate } \\
\text { under more normal market } \\
\text { conditions. }\end{array}$ \\
\hline $\begin{array}{l}\text { Schoonschip: } \\
\text { Sustainable floating } \\
\text { residential } \\
\text { community } \\
\text { ( } 30 \text { houses, } \\
\approx 48 \text { households) }\end{array}$ & $\begin{array}{l}\text { On particular innovations } \\
\text { (cleantech and smart grids) by } \\
\text { directly involved actors, such } \\
\text { as the municipality and the } \\
\text { local water company, and the } \\
\text { future residents. Since the } \\
\text { realisation of Schoonschip, the } \\
\text { systems can be improved } \\
\text { based on the feedback of } \\
\text { real-life users. }\end{array}$ & $\begin{array}{l}\text { The initiating (community of) } \\
\text { residents learned on how to } \\
\text { collaborate with knowledge } \\
\text { institutes and local partners as } \\
\text { key enablers to provide } \\
\text { support in terms of } \\
\text { knowledge, subsidies and } \\
\text { municipal support for } \\
\text { innovation. They also learned } \\
\text { how to organise the } \\
\text { community, to keep everyone } \\
\text { 'on board.' The affordability of } \\
\text { the housing at this location } \\
\text { became a supportive driver for } \\
\text { this when the economy } \\
\text { started to grow again. }\end{array}$ & $\begin{array}{l}\text { The municipality has learned } \\
\text { on the opportunity of floating } \\
\text { urban development, and on } \\
\text { how to collaborate with } \\
\text { citizens' initiatives. The } \\
\text { leading role of the community } \\
\text { of future residents in the } \\
\text { development of the concept } \\
\text { will reduce the direct } \\
\text { replicability of the concept by } \\
\text { other communities, the } \\
\text { municipality or developers, } \\
\text { since this may lead to other } \\
\text { demands and concepts. }\end{array}$ \\
\hline
\end{tabular}


Table 2. (Cont.) Learning and innovation resulting from three living labs in Amsterdam.

\begin{tabular}{|c|c|c|}
\hline ULL & Single-loop learning & Double-loop learning \\
\hline $\begin{array}{l}\text { Manifesto/Living } \\
\text { Lab Circular } \\
\text { Buiksloterham }\end{array}$ & $\begin{array}{l}\text { By the Buiksloterham } \\
\text { community and later the City } \\
\text { Lab, and the Manifesto } \\
\text { partners on opportunities for } \\
\text { sustainable and circular urban } \\
\text { development. }\end{array}$ & $\begin{array}{l}\text { By the initiators of the City Lab } \\
\text { with regards to the } \\
\text { formulation of ambitions and } \\
\text { laying it down in formal } \\
\text { statements, policy documents } \\
\text { and policy instruments, and in } \\
\text { building coalitions for support; } \\
\text { how a joint declaration can be } \\
\text { used to build momentum. }\end{array}$ \\
\hline
\end{tabular}

Triple loop learning

The community and later City Lab learned that having a formal declaration and status did not automatically lead to the implementation of ambitions; on the contrary, with the In the midst of the many sustainable innovations taking place, and new companies and residents moving into the newly developed plots in the area, the foundation City Lab had to reposition itself to keep its role and legitimacy as a knowledge broker and central contact for the municipality and stakeholders in the area. Without formal stakes in the area, in terms of land, buildings, or projects, it is difficult to claim such a position, both towards landowners/users/residents and the municipality and developers. To the central government, the City Lab does play a role in showcasing the benefits of a Manifesto and especially asking attention for removing regulatory barriers for implementation of innovations.

vative ideas, users can get the innovation they want, researchers can acquire case studies, and public organisations can get increased return on their innovation research investments (Stahlbröst \& Holst, 2013). Therefore, as a co-creative environment, ULLs can provide an essential platform to connect various impacts. This is also essential as the increasing number of social and environmental challenges we face involve actors from different organisations with different needs. The application of various learning loops, as has been demonstrated earlier, can demonstrate how people, organisations, and groups can modify their actions. In fact, these learning loops, theoretically speaking, are designed so that through open and engaged learning, the variety of actors involved during the process can contribute to the different phases of the innovation system via a collective learning mechanism (Concilio \& Molinari, 2014; Friedrich et al., 2013).

This kind of experimental approach not only brings a variety of different actors together but also recognises the value of partnerships and the different stakeholders and their roles in facilitating and supporting innovation (Mulvenna et al., 2010). However, when the learning theories are applied in real settings, the replication of innovation can be problematic because learning theories are especially concerned within a particular learning setting. In ULLs, on the other hand, actors learn within a particular context, while the expectations of policymakers, industry, citizens, and knowledge institutes is that the lessons learned will be useful for other contexts, i.e., the innovations need to be of use in other contexts as well. In our cases, what we have seen is that there is a wide range of actors involved in disseminating the learning and information.

In the case of De Ceuval and Schoonschip, various knowledge institutes, consultants and the local water company help to disseminate lessons to other locations within Amsterdam and beyond. On the other hand, for Manifesto/Living Lab Circular Buiksloterham, the City Lab exchanges experiences with similar 'bottom-up' ini- 
tiatives in other cities and promotes the relevance of the development of, and signed commitment to, shared ambitions amongst innovative stakeholders, local enterprises, (future) residents/users, and professional actors with a short- or long-term stake in the area. The innovations have been directed at small-scale developments, set in the midst of the financial crisis when largescale development was something of the past. However, once the projects are set up and stakeholders identified, the learning processes and governance leading to co-production of knowledge remains ambiguous mainly due to the more informal relationship between private and public stakeholders. The same thing also applies in relation to citizen involvement. Nevertheless, to be able to develop a learning ecosystem where reciprocal experiences remain essential for replicating innovation and embedding the learning, it is essential to develop the 'community' relations between various stakeholders.

\section{Conclusion}

This article draws on qualitative evidence collected from three ULLs in Amsterdam to convey some of the diversity in local practice and experiences. While some conceptualised their ULL activities explicitly in terms of structured learning through experimentation, e.g., driven by requirements of granted subsidies, other learning processes were more informal. There can be an element of learning-by-doing, where local actors are discovering for themselves, for example, the possibilities for seeking innovative solutions. The case studies provide examples of actors bringing stakeholders together to sensitise them to the possibilities of local innovations. We have also shown that ULLs display a large emphasis on learning. These learning processes have been further specified with the help of an analysis of the most important learning models from learning literature. Through interviews with participants in the ULLs, the learning processes in ULLs in Amsterdam have been investigated and compared to the theoretical hypotheses. This has led to insight on where and why practice deviates from theory regarding the learning processes in ULLs, appointing areas of attention for the successful implementation of learning processes in ULLs in practice and already allowing us to draw some lessons in this field.

When comparing the real enrolment of learning processes in ULLs in practice to theory, we see one large difference between the theoretical representation of learning and the situation in practice. The established learning models rely on or simplify the real situation according to the hypothesis that all learning activities are performed by one actor and take place in the same system. Practice shows us that in ULLs however, it is not the learning ULL that must apply the lessons, it is another project that must do so (Mulvenna et al., 2010). This creates what can be considered a learning ecosystem in which the overall learning process goes across actors and projects, not applying to living labs on an individual level, but to sustain- able urban development projects as a system (Friedrich et al., 2013). This requires some sort of 'interactive collective social learning model,' in which learning is not acquired from personal experiences, but from reciprocal experiences, very much emphasizing the importance of transfer and distribution of lessons/knowledge.

Today, the embrace of experimental urbanism results in diverse innovative activities interacting with existing infrastructures, governance structures, and sociopolitical legacies (Hodson, Geels, \& McMeekin, 2017, p. 8). While the institutional matrix through which experimentation occurs diverges markedly between urban areas (Raven, Kern, Verhees, \& Smith, 2016), multiple experiments can be conducted simultaneously within the same urban space and to think in terms of transitions. Cities facing declining public resources are driven to seek cost savings, alternative income sources, and new activities to sustain local economies; ULLs offer an alternative bottom-up approach. As technology advances, new social actors join collaborations, necessitating further rounds of learning. Nevertheless, the transition through which ULLs move from small-scale pilots to broader social embedding is a precarious process without a solid institutional framework. As the cases have shown in this exploration, this may lead to a mismatch between the scale and context of experiments, e.g., innovations that can only be applied on a small scale, innovations that require an existing community of (future) residents, or a formal status existing but without any institutional embedding in terms of political support, position, resources, or influence.

\section{Acknowledgments}

The authors acknowledge the contribution of Kris Gyselle Steen in conducting interviews for the cases and developing the interview protocol using the timeline.

\section{Conflict of Interests}

The authors declare no conflict of interests.

\section{References}

Araos, M., Berrang-Ford, L., Ford, J. D., Austin, S. E., Biesbroek, R., \& Lesnikowski, A. (2016). Climate change adaptation planning in large cities: A systematic global assessment. Environmental Science \& Policy, 66, 375-382.

Argyris, C., \& Schön, D. (1978). Organizational learning: A theory of action approach. Reading, MA: Addision Wesley.

Arnkil, R., Järvensivu, V., Koski, P., \& Piirainen, T. (2010). Exploring Quadruple Helix: Outlining user-oriented innovation models (Working Paper Työraportteja 85/2010). Tampere: Institute for Social Research of the University of Tampere.

Bennett, C. J., \& Howlett, M. (1992). The lessons of learn- 
ing: Reconciling theories of policy learning and policy change. Policy Sciences, 25(3), 275-294.

Brown, H., \& Vergragt, P. (2008). Bounded sociotechnical experiments as agents of systemic change: The case of a zero energy residential building. Technological Forecasting \& Social Change, 75, 107-130.

Brown, H., Vergragt, P., Green, K., \& Berchicci, L. (2003). Learning for sustainable transition through bounded socio-technical experiments in personal mobility. Technology Analysis \& Strategic Management, 15(3), 291-315.

Bulkeley, H., Coenen, L., Frantzeskaki, N., Hartmann, C., Kronsell, A., Mai, L., . . Palgan, Y. V. (2016). Urban living labs: Governing urban sustainability transitions. Current Opinion in Environmental Sustainability, 22, 13-17.

Carayannis, E. G., \& Campbell, D. (2009). 'Mode 3' and 'Quadruple Helix': Toward a 21st century fractal innovation ecosystem. International Journal of Technology Management, 46(3/4), 201-234.

Chesbrough, H. W. (2003). Open innovation: The new imperative for creating and profiting from technology. Boston, MA: Harvard Business School Press.

Concilio, G., \& Molinari, F. (2014). Urban living labs: Learning environments for collective behavioural change. In D. Carlucci, J. Spender, \& G. Schiuma (Eds.), Knowledge and management models for sustainable growth (pp. 746-763). Matera: IFKAD.

Cunningham, J., \& Cunningham, S. (2008). Sociology and social work. Exeter: Learning Matters.

Ersoy, A. (2017). Impact of co-production. Bristol: Policy Press.

Franz, Y., Tausz, K., \& Thiel, S.-K. (2015). Contextuality and co-creation matter: A qualitative case study comparison of living lab concepts in urban research. Technology Innovation Management Review, 5(12), 48-55.

Friedrich, P., Karlsson, A., \& Federley, M. (2013). Report 2.1: Boundary conditions for successful urban living labs. The Hague: SubUrbanLab. Retrieved from https://www.ivl.se/download/18.4b1c947d15125e7 2dda353c/1452527645173/C152.pdf

Gibbons, M., Limoges, C., Nowotny, H., Schwartzman, S., Scott, P., \& Trow, M. (1994). The new production of knowledge: The dynamics of science and research in contemporary societies. London: Sage.

Gladek, E., van Odijk, S., Theuws, P., \& Herder, A. (2015). Transitioning Amsterdam to a circular city: Circular Buiksloterham. Amsterdam: Metabolic, Studioninedots, and DELVA Landscape Architects. Retrieved from https://www.metabolic.nl/publications/ circular-buiksloterham-roadmap-amsterdams-firstcircular-neighborhood

Hargrove, R. (2002). Masterful coaching. Hoboken, NJ: Wiley.

Higgins, A., \& Klein, S. (2011). Introduction to the living lab approach. In Y. H. Tan, N. Bjørn-Andersen, S. Klein \& B. Rukanova (Eds.), Accelerating global supply chains with IT-innovation (pp. 31-36). Berlin: Springer.

Hodson, M., Geels, F., \& McMeekin, A. (2017). Reconfiguring urban sustainability transitions, analysing multiplicity. Sustainability, 9. https://doi.org/10.3390/ su9020299

Jasanoff, S. (Ed.). (2004). States of knowledge: The coproduction of science and the social order. Abingdon: Routledge.

Joint Research Centre. (n.d.). Living labs for regional innovation ecosystems. Brussels: European Commission. Retrieved from https://s3platform.jrc.ec.europa.eu/ documents/20182/138085/Living+labs+for+ regional+innovation+ecosystems_update.pdf/ 7197a890-a0c2-4db6-9e7a-58fd7f63e20d

JPI Urban Europe. (2013). Urban living labs by JPI Urban Europe. Vienna: JPI Urban Europe. Retrieved from https://jpi-urbaneurope.eu/app/uploads/2018/ 01/Urban-Living-Labs-info-sheet-draft-171123version-8.2-PRINT.pdf

Juujärvi, S., \& Pesso, K. (2013). Actor roles in an urban living lab: What can we learn from Suurpelto, Finland? Technology Innovation Management Review, 3(11), 22-27.

Karvonen, A., \& van Heur, B. (2014). Urban laboratories: Experiments in reworking cities. International Journal of Urban and Regional Research, 38(2), 379-392.

Lehmann, V., Frangioni, M., \& Dubé, P. (2015). Living Lab as knowledge system: An actual approach for managing urban service projects? Journal of Knowledge Management, 19(5), 1087-1107.

Leydesdorff, L. (2006). The knowledge-based economy: Modeled, measured, simulated. Boca Raton, FL: Universal Publishers.

Matti, C., Edwards-Schachter, M. E., \& Alcántara, E. (2012). Fostering quality of life through social innovation: A living lab methodology study case. Review of Policy Research, 29(6), 672-692.

Menny, M., Palgan, Y. V., \& McCormick, K. (2018). Urban living labs and the role of users in co-creation. GAIAEcological Perspectives for Science and Society, 27(1), 68-77.

Mulvenna, M., Bergvall-Kåreborn, B., Wallace, J., Galbraith, B., \& Martin, S. (2010). Living labs as engagement models for innovation. Paper presented at eChallenges e-2010 Conference, Warsaw, Poland.

Nowotny, H., Scott, P., Gibbons, M., \& Scott, P. B. (2001). Re-thinking science: Knowledge and the public in an age of uncertainty. Cambridge: Polity.

Nyström, A. G., Leminen, S., Westerlund, M., \& Kortelainen, M. (2014). Actor roles and role patterns influencing innovation in living labs. Industrial Marketing Management, 43(3), 483-495.

Pahl-Wostl, C. (2009). A conceptual framework for analysing adaptive capacity and multi-level learning processes in resource governance regimes. Global Environmental Change, 19(3), 354-365.

Pallot, M., Trousse, B., Senach, B., \& Scapin, D. (2010). Liv- 
ing lab research landscape: From user centred design and user experience towards user cocreation. Paper presented at First European Summer School "Living Labs," Paris, France. Retrieved from https://hal.inria. fr/inria-00612632/document

Pereira, L., Karpouzoglou, T., Doshi, S., \& Frantzeskaki, N. (2015). Organising a safe space for navigating socialecological transformations to sustainability. International Journal of Environmental Research and Public Health, 12(6), 6027-6044.

Perry, B., \& Atherton, M. (2017). Beyond critique: The value of co-production in realising just cities? Local Environment, 22, 36-51.

Polk, M. (2015). Transdisciplinary co-production: Designing and testing a transdisciplinary research framework for societal problem solving. Futures, 65, 110-122.

Raven, R., Kern, F., Verhees, B., \& Smith, A. (2016). Niche construction and empowerment through sociopolitical work: A meta-analysis of six low carbon cases. Environmental Innovation and Societal Transitions, 18, 164-180.

Schuurman, D., Baccarne, B., Marez, L. D., Veeckman, C., \& Ballon, P. (2016). Living Labs as open innovation systems for knowledge exchange: Solutions for sustainable innovation development. International Journal of Business Innovation and Research, 10(2/3), 322-340.
Stahlbröst, A., \& Holst, M. (2013). The living lab methodology handbook. Luleå: Luleå University of Technology. Retrieved from http://www.Itu.se/cms_fs/ 1.101555!/file/LivingLabsMethodologyBook_web.pdf

Steen, K. Y. G., \& van Bueren, E. M. (2016). Learning beyond urban experiments: Lessons from Amsterdam urban living labs (Draft 24/02/2017). Unpublished manuscript.

Stone-Jovicich, S. (2015). Probing the interfaces between the social sciences and social-ecological resilience: Insights from integrative and hybrid perspectives in the social sciences. Ecology and Society, 20(2). http:// dx.doi.org/10.5751/ES-07347-200225

Teisman, G. R. (2000). Models for research into decision-making processes: On phases, streams and decision-making rounds. Public Administration, 78(4), 937-956.

Wyborn, C. (2015). Co-productive governance: A relational framework for adaptive governance. Global Environmental Change, 30, 56-67.

van Bueren, E., \& De Jong, J. (2007). Establishing sustainability: Policy successes and failures. Building Research \& Information, 35(5), 543-556.

Voytenko, Y., McCormick, K., Evans, J., \& Schliwa, G. (2016). Urban living labs for sustainability and low carbon cities in Europe: Towards a research agenda. Journal of Cleaner Production, 123, 45-54.

\section{About the Authors}
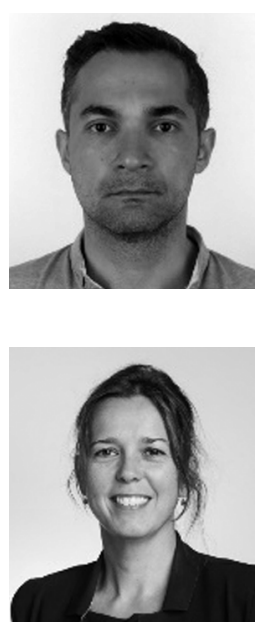

Aksel Ersoy works as an Assistant Professor in Urban Development Management at TU Delft. His research and teaching focus on the governmentality of the future city, urban environment and urban infrastructure. He is also a part of the AMS Institute for Advanced Metropolitan Solutions and the Leiden-Delft-Erasmus Centre for Sustainability.

Ellen van Bueren is a Professor of Urban Development Management at TU Delft. Her research and teaching focus on the governance and management of sustainable urban development and aims to develop usable approaches, practices, methods, and tools to address the multi-level and multistakeholder dynamics of planning and decision-making on the urban and built environment. She is involved in multiple transdisciplinary environments for research and education, including the AMS Institute for Advanced Metropolitan Solutions and the Leiden-Delft-Erasmus Centre for Sustainability. 